\section{Scientific journal}

\section{PHYSICAL AND MATHEMATICAL EDUCATION}

Has been issued since 2013.

Науковий журнал

ФІЗИКО-МАТЕМАТИЧНА ОСВІТА

Видається з 2013.
ISSN 2413-158X (online)

ISSN 2413-1571 (print)

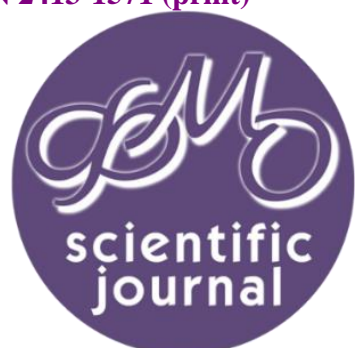

Друшляк М.Г. Формування візуально-інформаційної культури майбутніх учителів математики та інформатики: ресрлексивно-оцінювальний критерій. Фізико-математична освіта. 2021. Випуск 4(30). С. 54-60.

Drushlyak M. Formation of visual and information culture of pre-service mathematics and computer science teachers: reflexive and evaluative criterion. Physical and Mathematical Education. 2021. Issue 4(30). P. 54-60.

DOI 10.31110/2413-1571-2021-030-4-008

УдК 378.14: 371.214.46

М.Г. Друшляк

Сумський державний педагогічний університет імені А.С. Макаренка, Україна marydru@fizmatsspu.sumy.ua

ORCID: https://orcid.org/0000-0002-9648-2248

\title{
ФОРМУВАННЯ ВІЗУАЛЬНО-ІНФОРМАЦІЙНОЇ КУЛЬТУРИ МАЙБУТНІХ УЧИТЕЛІВ МАТЕМАТИКИ ТА ІНФОРМАТИКИ: РЕФЛЕКСИВНО-ОЦІНЮВАЛЬНИЙ КРИТЕРІЙ
}

Формулювання проблеми. Сучасний вчитель математики та інформатики повинен мати високий рівень сформованості візуально-інформаційної культури, структурі якої з необхідністю виділяємо рефлексивний компонент, що характеризується здатністю до аналізу, прогнозування і рефлексії власної професійної діяльності з візуалізації навчального матеріалу з використанням засобів комп'ютерної візуалізації, яка забезпечує професійний саморозвиток і самовдосконалення.

Матеріали і методи. Основою дослідження стали наукові розвідки вітчизняних і закордонних учених, які займаються вивченням питань підготовки майбутніх вчителів математики та інформатики. Для досягнення мети були використані методи теоретичного рівня наукового пізнання: аналіз наукової літератури, синтез, формалізація наукових джерел, опис, зіставлення та статистичний метод - $t$-критерій Стьюдента.

Результати. Для визначення рівня сформованості візуально-інформаційної культури майбутніх учителів математики та інформатики виокремлено серед іншого ресллексивно-оцінювальний критерії, який характеризується здатністю до самоаналізу, оцінювання та рефлексивної інтерпретації результатів власної професійної діяльності щодо впровадження засобів комп'ютерної візуалізації в освітній процес. Статистичні розрахунки за показниками рефлексивно-оцінювального критерію (критичне ставлення до обраного засобу комп'ютерної візуалізації, до обраної технології візуалізації навчального контенту, усвідомлення типових помилок при впровадженні інформаційних технологій у освітній процес (P1 «Здатність до самоаналізу»); потреба у самовдосконаленні, у оновленні і поповненні власних знань, умінь та навичок у галузі інформатико-математичних дисциплін та цифрових технологій (Р2 «Здатність до самовдосконалення») підтвердили статистичну відмінність обраних сукупностей: по кожній парі сукупностей ЕГ1 - КГ і ЕГ2 - КГ по кожному показнику отримано $\left|t_{\text {стат }}\right|>t_{\text {крит }}$ та статистичну однорідність по групам $E Г 1-E Г 2$, оскільки по кожному показнику отримано $\left|t_{\text {стат }}\right|<t_{\text {крит }}$.

Висновки. За результатами впровадження системи формування візуально-інформаційної культури майбутніх учителів математики та інформатики студенти проявляли критичне ставлення до обраного засобу комп'ютерної візуалізації в ході написання конспектів уроків чи розв'язування професійних завдань, бажання обговорювати шляхи використання засобів комп'ютерної візуалізації при вивченні певних тем икільного курсу математики, інформатики з подальшим аналізом та корекиією власної професійної діяльності, усвідомлення типових помилок при застосуванні інформаційних технологій в освітньому процесі, зацікавленість у поповненні власних знань у галузі когнітивної візуалізації за рахунок вивчення досвіду інших, опрацювання науково-методичної літератури.

КлЮчОВІ СлОвА: візуально-інформаційна культура, майбутні вчителі математики та інформатики, рефлексія, рефлексивний компонент візуально-інформаційна культури, рефлексивно-оцінювальний критерій.

\section{ВСТуп}

Постановка проблеми. Сучасний вчитель математики та інформатики повинен мати високий рівень сформованості візуально-інформаційної культури, тобто повинен мати ціннісні установки, прагнення до розвитку в галузі візуалізації та інформатизації освіти; володіти інформатико-математичні, психолого-педагогічні та технологічні знаннями; уміннями сприймати, аналізувати, порівнювати, зіставляти, інтерпретувати, продукувати з використанням інформаційних 
технологій, структурувати, інтегрувати, оцінювати поданий наочно навчальний матеріал. Але окрім зазначених складових у структурі візуально-інформаційної культури майбутніх учителів математики та інформатики виділяємо також рефлексивний компонент, що характеризується здатністю до аналізу, прогнозування і рефлексії власної професійної діяльності з візуалізації навчального матеріалу з використанням засобів комп'ютерної візуалізації, яка забезпечує професійний саморозвиток і самовдосконалення.

Рефлексію розуміємо як спосіб аналітичної діяльності, спрямований на критичне осмислення власного «Я», своєї діяльності, що дозволяє прогнозувати та корегувати власну подальшу професійну діяльність, і в такому контексті вона відіграє визначальну роль у професійній діяльності. Важливість ролі рефлексивних механізмів у професійній діяльності вбачаємо у забезпеченні умови подальшого професійного саморозвитку та самовдосконалення у педагогічному, методичному та технологічному аспектах.

Усвідомлений саморозвиток майбутнього вчителя математики та інформатики означає самозбагачення, яке усвідомлюється, схвалюється та є бажаним. Процес саморозвитку забезпечує послідовну зміну особистісних станів, де кожний наступний $€$ удосконаленням попереднього. У цьому контексті рефлексію мислимо як потребу у оновленні і поповненні власних знань, умінь та навичок у галузі математичних та інформатичних дисциплін, цифрових технологій.

Рефлексивні дії дозволяють індивідуалізувати власну професійну діяльність, здійснювати самоаналіз, оцінювання та рефлексивну інтерпретацію власної професійної діяльності щодо впровадження засобів комп'ютерної візуалізації в освітній процес, що сприяє вибору педагогічно доцільних стратегій коригування подальшої діяльності з метою усунення власних недоліків. Невід'ємною складовою сформованості візуальноінформаційної культури майбутніх учителів математики та інформатики є критичне ставлення до обраного засобу когнітивної візуалізації, до обраної технології візуалізації навчального контенту. За допомогою педагогічної рефлексії відбувається зіставлення обраних шляхів професійної діяльності оптимальним методичним і педагогічним зразкам.

Для визначення рівня сформованості візуально-інформаційної культури майбутніх учителів математики та інформатики виокремлено мотиваційний (Друшляк, 2020b), пізнавальний (Друшляк, 2021), процесуальний (Друшляк, 2020с) та рефлексивно-оцінювальний критерії (Друшляк, 2020а).

Мета статті. Визначити рівень сформованості візуально-інформаційної культури майбутніх учителів математики та інформатики за рефлексивно-оцінювальним критерієм.

\section{МЕТОДИ ДОСЛІДЖЕННЯ}

Основою дослідження стали наукові розвідки вітчизняних і закордонних учених, які займаються вивченням питань підготовки майбутніх вчителів математики та інформатики. Для досягнення мети були використані методи теоретичного рівня наукового пізнання: аналіз наукової літератури, синтез, формалізація наукових джерел, опис, зіставлення та статистичний метод - t-критерій Стьюдента.

\section{РЕЗУЛЬТАТИ}

Рефлексивно-оцінювальний критерій характеризується здатністю до самоаналізу, оцінювання та рефлексивної інтерпретації результатів власної професійної діяльності щодо впровадження засобів комп'ютерної візуалізації в освітній процес. Показниками рефлексивно-оцінювального критерію є: критичне ставлення до обраного засобу комп'ютерної візуалізації, до обраної технології візуалізації навчального контенту, усвідомлення типових помилок при впровадженні інформаційних технологій у освітній процес (шифр Р1 - «Здатність до самоаналізу»); потреба у самовдосконаленні, у оновленні і поповненні власних знань, умінь та навичок у галузі інформатико-математичних дисциплін та цифрових технологій (шифр Р2 «Здатність до самовдосконалення»).

У експерименті брали участь 431 студенти спеціальностей 014.04 «Середня освіта (Математика)» та 014.09 «Середня освіта (Інформатика)», з яких 151 особа увійшла до першої експериментальної групи (ЕГ1) (студенти спеціальності 014.04 «Середня освіта (Математика)»), 122 особа увійшла у другу експериментальну групу (ЕГ2) (студенти спеціальності 014.09 «Середня освіта (Інформатика), а 158 осіб - у контрольну групу (КГ). Студенти експериментальних груп навчалися за авторською системою формування візуально-інформаційної культури майбутніх учителів математики та інформатики (Друшляк, 2019). Це були студенти, які вступали до ЗВО у 2015-2017 р.р. Контингент студентів, які вступали у ці роки на спеціальності 014.04 «Середня освіта (Математика)» та 014.09 «Середня освіта (Інформатика)» по Україні наведено у Таблиці 1 (Єдина державна електронна база з питань освіти).

У даному випадку репрезентативність вибірки забезпечується 10\% від загальної кількості вступників на спеціальності 014.04 «Середня освіта (Математика)» та 014.09 «Середня освіта (Інформатика)» (див. Таблицю 1) і має бути не менше 405 осіб. Отже, обрана нами кількість учасників експерименту є достатньою.

Узагальнені результати контрольних зрізів та динаміка по кожному показнику (у відсотках) наведено у Таблиці 2 з метою констатації змін, які відбулися у експериментальних групах внаслідок впровадження 
педагогічної системи формування візуально-інформаційної культури майбутніх учителів математики та інформатики у закладах вищої освіти.

Таблиця 1

Контингент студентів спеціальностей

«Середня освіта (Математика)» та «Середня освіта (Інформатика)»

\begin{tabular}{|c|c|c|c|c|c|}
\hline Спеціальність & 2015 & 2016 & 2017 & 2018 & Разом \\
\hline 014.04 Середня освіта (Математика) & 940 & 492 & 599 & 406 & 2437 \\
\hline 014.09 Середня освіта (Інформатика) & 854 & 384 & 268 & 216 & 1622 \\
\hline
\end{tabular}

Таблиця 2

Результати діагностичних зрізів у експериментальних та контрольній групах на початку та наприкінці експерименту (у \%)

\begin{tabular}{|c|c|c|c|c|c|c|c|c|c|}
\hline \multirow[b]{2}{*}{ Показник } & \multicolumn{3}{|c|}{ ЕГ1 } & \multicolumn{3}{|c|}{ ЕГ2 } & \multicolumn{3}{|c|}{$\mathrm{K} \Gamma$} \\
\hline & 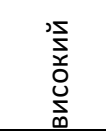 & 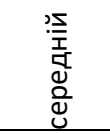 & 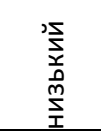 & 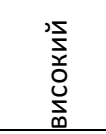 & 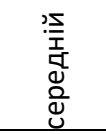 & 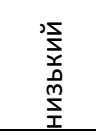 & 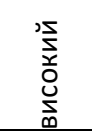 & 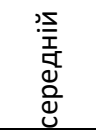 & $\begin{array}{l}\stackrel{י}{\Sigma} \\
\stackrel{s}{\mathbf{r}} \\
\stackrel{m}{\Sigma}\end{array}$ \\
\hline P1 (до) & 6,62 & 43,05 & 50,33 & 6,56 & 37,70 & 55,74 & 5,70 & 40,51 & 53,80 \\
\hline P1 (після) & 22,52 & 56,29 & 21,19 & 21,31 & 51,64 & 27,05 & 8,86 & 49,37 & 41,77 \\
\hline P1 (різниця) & $+15,89$ & $+13,25$ & $-29,14$ & $+14,75$ & $+13,93$ & $-28,69$ & $+3,16$ & $+8,86$ & $-12,03$ \\
\hline Р2 (до) & 16,56 & 43,71 & 39,74 & 16,39 & 40,98 & 42,62 & 15,82 & 43,67 & 40,51 \\
\hline P2 (після) & 27,15 & 56,95 & 15,89 & 27,05 & 55,74 & 17,21 & 20,82 & 51,27 & 27,85 \\
\hline P2 (різниця) & $+10,60$ & $+13,25$ & $-23,84$ & $+10,66$ & $+14,75$ & $-25,41$ & $+5,06$ & $+7,59$ & $-12,66$ \\
\hline
\end{tabular}

Для порівняння середніх контрольної та експериментальних груп нами використовувався t-критерій Стьюдента. Отримане значення t-критерію порівнювалося із $t_{\text {крит }}=1,96$ для рівня значущості 0,05 . Будувалася нульова гіпотеза: середні в групах ЕГ та КГ однакові. Для ії прийняття має виконуватися вимога

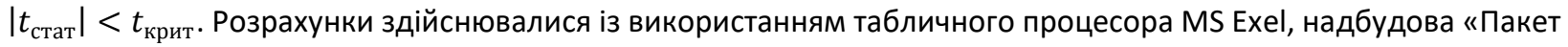
аналізу», вкладка Данные/Анализ данных/ Друхвыборочный t-тест для средних с различными дисперсиями. Статистичні розрахунки за всіма критеріями, крім Р1, підтвердили рівність середніх обраних сукупностей - по

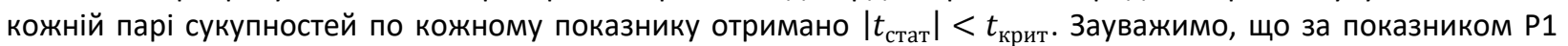
«Здатність до самоаналізу» шкала вимірювання була від 60 до 0, тобто «найнижчий» бал був 60, «найвищий» - 0. Ми не інвертували дану шкалу, тому при розрахунках можливим був варіант, коли $t_{\text {стат }}<0$, отже критерієм прийняття альтернативної гіпотези була нерівність $\left|t_{\text {стат }}\right|>t_{\text {крит }}$.

За результатами формувального експерименту знову було сформульовано нульову гіпотезу: експериментальні групи ЕГ1, ЕГ2 і контрольна група КГ мають статистично однакові середні та альтернативну гіпотезу: експериментальні групи ЕГ1, ЕГ2 і контрольна група КГ мають статистично різні середні. Для того, щоб прийняти альтернативну гіпотезу і стверджувати, що наприкінці експерименту у ЕГ1 та ЕГ2 було

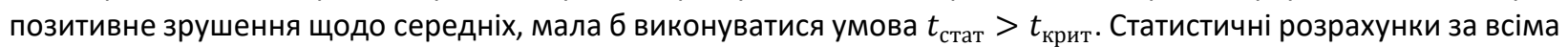
показниками рефлексивно-оцінювального критерію підтвердили статистичну відмінність обраних сукупностей: по кожній парі сукупностей ЕГ1 - КГ і ЕГ2 - КГ по кожному показнику (зауваження щодо показника Р1 зберігається) отримано $\left|t_{\text {стат }}\right|>t_{\text {крит }}$ та статистичну однорідність по групам ЕГ1 - ЕГ2, оскільки по кожному показнику (зауваження щодо показника Р1 зберігається) отримано $\left|t_{\text {стат }}\right|<t_{\text {крит }}$.

\section{ОБГОВОРЕННЯ}

Рівень сформованості показника Р1 визначався за результатами залікових лабораторних робіт, в ході яких студенти демонстрували розроблені уроки чи фрагменти уроків із використанням засобів комп'ютерної візуалізації. Самоаналіз уроку здійснювався за тією ж схемою, за якою викладач оцінював проведений урок (схема містить 60 критеріїв і наведена у Таблиці 3).

Бали визначалися за формулою:

$\alpha=$ «Оцінка студента» - «Оцінка викладача»,

де величина $\alpha$ належить відрізку [-60;60]. Причому, якщо $\alpha \in(0 ; 60]$, то досліджуваний оцінив себе вище, ніж його оцінив викладач, якщо $\alpha \in(-60 ; 0]$, то навпаки, досліджуваний оцінив себе нижче, ніж це зробив викладач. Але у даному дослідженні нас цікавить саме «адекватність» самооцінювання, тобто відхилення від певного «еталону» - оцінки викладача. Тому ми беремо до уваги відкоригований бал $|\alpha|$, який належить відрізку $[0 ; 60]$. 
Таблиця 3

Схема аналізу уроку із використанням ЗКВ

\begin{tabular}{|c|c|c|c|c|c|}
\hline \multirow[t]{2}{*}{ № } & \multirow{2}{*}{\multicolumn{3}{|c|}{ Критерій оцінювання }} & \multicolumn{2}{|c|}{ Оцінка } \\
\hline & & & & викл. & студ. \\
\hline 1 & \multicolumn{3}{|l|}{ Відповідність навчальній програмі. } & & \\
\hline 2 & \multicolumn{3}{|c|}{ Раціонально обрано тип уроку відповідно до мети. } & & \\
\hline 3 & \multicolumn{3}{|c|}{ Раціонально обрано метод навчання відповідно до мети. } & & \\
\hline 4 & \multicolumn{3}{|c|}{ Раціонально та ефективно обрано організаційні форми роботи відповідно до мети. } & & \\
\hline 5 & \multicolumn{3}{|c|}{ Органічне поєднання обраних форм, прийомів та методів навчання. } & & \\
\hline 6 & \multicolumn{3}{|l|}{ Витримана структура уроку. } & & \\
\hline 7 & \multicolumn{3}{|l|}{ Наявна актуалізація опорних знань. } & & \\
\hline 8 & \multicolumn{3}{|c|}{ При актуалізації опорних знань використано ЗКВ. } & & \\
\hline 9 & & & \\
\hline 10 & \multicolumn{3}{|l|}{ Наявні елементи повторення. } & & \\
\hline 11 & & & програми комп'ютерного тестування & & \\
\hline 12 & & & презентації & & \\
\hline 13 & використано & & відео & & \\
\hline 14 & & & когнітивно-візуальні моделі & & \\
\hline 15 & & & QR-коди & & \\
\hline 16 & & & хмаро орієнтовані сервіси & & \\
\hline 17 & Завдання для повторення дифен & ннці & & & \\
\hline 18 & Всі учні задіяні перевіркою знан & & & & \\
\hline 19 & Миттєві результати перевірки зң & Hь. & & & \\
\hline 20 & Вивчення нового матеріалу & & & & \\
\hline 21 & Раціональний добір матеріалу д & $\phi$ & зання умінь та навичок. & & \\
\hline 22 & & & ться історичні відомості (із залученням IKT) & & \\
\hline 23 & & & ем використовуються когнітивно-візуальні моделі & & \\
\hline 24 & При вивченні нового матеріалу & & овано комп'ютерний експеримент & & \\
\hline & & & ться контрприклади & & \\
\hline 25 & & & стано хмарні сервіси математичного спрямування & & \\
\hline 26 & Наявність самостійної роботи пі & 4ac & плення. & & \\
\hline 27 & Для виконання самостійної робс & $n \pi$ & Бачено інструкції. & & \\
\hline 28 & Наявність домашнього завдання & & & & \\
\hline 29 & & & індивідуальне & & \\
\hline 30 & & & групове & & \\
\hline 31 & Домашнє завдання & & розраховано на різні групи учнів & & \\
\hline 32 & & & із залученням засобів когнітивної візуалізації & & \\
\hline 33 & & & із залученням хмаро орієнтованих сервісів & & \\
\hline 34 & При повідомленні завдань & & джерела інформації & & \\
\hline & конкретизовано & & програму чи ресурс & & \\
\hline & & & інструктаж & & \\
\hline & & & форму звітності & & \\
\hline 35 & Наявність зворотнього зв'язку, о & іню & я відповідей. & & \\
\hline 36 & Учні працюють за комп'ютерами & $\mathrm{cam}$ & но/ у групах. & & \\
\hline 37 & Учні працюють за комп'ютерами & одн & чо/ по черзі. & & \\
\hline 38 & Витримано вимоги щодо часу пє & e6 & я учнів за комп'ютером відповідно до їх віку. & & \\
\hline 39 & Відведено окремий час для опа & ван & овим інструментарієм. & & \\
\hline 40 & Наявність інструкцій для кожног & учн & забезпечення індивідуального темпу роботи. & & \\
\hline 41 & & & завдання & & \\
\hline 42 & & & повідомлення про час виконання & & \\
\hline 43 & & & алгоритм побудови & & \\
\hline 44 & Інструкція містить & & таблиці для занесення результатів & & \\
\hline 45 & & & повідомлення про форму звітності & & \\
\hline 46 & & & додаткові/творчі завдання & & \\
\hline 47 & Раціонально обрано засіб комп' & тер & зуалізації відповідно до мети. & & \\
\hline 48 & Когнітивно-візуальна модель вің & OOBi & идактичній меті. & & \\
\hline 49 & Когнітивно-візуальна модель інс & $\mathrm{ppM}$ & на (форма, вимірювання, позначення, таблиці). & & \\
\hline 50 & Когнітивно-візуальна модель ст & pet & сно (колір, композиція, графічні елементи). & & \\
\hline 51 & Передбачено роздатковий мате & & & & \\
\hline 52 & & & формулювання завдання & & \\
\hline 53 & & & таблиці для занесення результатів & & \\
\hline 54 & Роздатковий матеріал & & місце для формулювання висновків & & \\
\hline 55 & & & додаткові/творчі завдання & & \\
\hline 56 & & & завдання для контролю знань & & \\
\hline 57 & Позитивний емоційний клімат н & ypc & & & \\
\hline 58 & Наявність інтересу учнів до урок & (до & ту, методів і форм). & & \\
\hline 59 & $\begin{array}{l}\text { Раціональність та ефективність } \\
\text { зміни видів діяльності в ході урс }\end{array}$ & KOF & ння часу уроку, оптимальність темпу, а також чергування і & & \\
\hline 60 & Рівень досягнення мети уроку. & & & & \\
\hline
\end{tabular}


Високий рівень сформованості показника «Здатність до самооцінки» у майбутніх учителів математики та інформатики відображає сума балів від 0 до 10; середній рівень - 11-20 балів, низький рівень - 21-60 бали.

Рівень сформованості показника Р2 визначався за методикою «Диспозиційна характеристика саморозвитку особистості - ДХСО» (Кузікова \& Кузіков, 2010) (Таблиця 4). Опитувальник містить 30 тверджень, які розподілено за трьома шкалами: потреба у саморозвитку, умови саморозвитку, механізми саморозвитку.

Таблиця 4

Методика «Диспозиційна характеристика саморозвитку особистості - ДХСО» (С. Кузікова)

\begin{tabular}{|c|c|c|c|c|c|c|}
\hline № & Запитання & 1 & 2 & 3 & 4 & 5 \\
\hline 1. & Я прагну вивчити і зрозуміти себе. & & & & & \\
\hline 2. & Я постійно займаюся самовдосконаленням. & & & & & \\
\hline 3. & Наявні життєві труднощі стимулюють мою активність. & & & & & \\
\hline 4. & В житті я визначився з близькими і далекими цілями. & & & & & \\
\hline 5. & Мені не вдається повною мірою використовувати свої сили і здібності. & & & & & \\
\hline 6. & Мене цікавить мій внутрішній світ і внутрішній світ інших людей. & & & & & \\
\hline 7. & $\begin{array}{l}\text { Мені подобається займатися справами, які вимагають від мене максимального } \\
\text { напруження й зусиль. }\end{array}$ & & & & & \\
\hline 8. & Я систематично аналізую і коригую свої почуття, думки, вчинки. & & & & & \\
\hline 9. & Мене ображає, коли люди ставляться до мене не так, як я хотів би. & & & & & \\
\hline 10. & Я часто відчуваю незадоволеність ступенем своєї самореалізації. & & & & & \\
\hline 11. & Мені важливо знати як інші люди сприймають мене. & & & & & \\
\hline 12. & Я вірю у свої потенційні можливості і прагну до їх максимальної реалізації. & & & & & \\
\hline 13. & Я не помічаю, щоб у ході життя я змінювався і ставав іншим. & & & & & \\
\hline 14. & Моє життя наповнене цікавими справами. & & & & & \\
\hline 15. & В своєму житті я намагаюсь керуватися ідеалами істини, добра, краси. & & & & & \\
\hline 16. & Я поки повністю не усвідомив свої потреби і цілі. & & & & & \\
\hline 17. & Я прагну постійно підвищувати рівень майстерності та компетентності. & & & & & \\
\hline 18. & Для мене неважлива думка інших про мене і життя в цілому. & & & & & \\
\hline 19. & Я керую своїм професійним розвитком і отримую позитивні результати. & & & & & \\
\hline 20. & В моєму житті було мало цікавих зустрічей, захоплень, подій, пригод. & & & & & \\
\hline 21. & Для мене важливо зрозуміти сенс свого існування. & & & & & \\
\hline 22. & Якщо я зробив помилку, я її ретельно аналізую і перебудовуюсь. & & & & & \\
\hline 23. & Зростаюча відповідальність і складність життєвих завдань лякають мене. & & & & & \\
\hline 24. & $\begin{array}{l}\text { Важливий для мене факт (подія, фільм, книга) я обдумую (приміряю до себе), } \\
\text { обговорюю зі значущими іншими. }\end{array}$ & & & & & \\
\hline 25. & Я отримую задоволення від пізнання і освоєння нового. & & & & & \\
\hline 26. & В мене не виходить повністю управляти своїми емоціями, почуттями, поведінкою. & & & & & \\
\hline 27. & Я вважаю, що нерозумно витрачати час на читання і роздуми. & & & & & \\
\hline 28. & Я не прагну бути відкритою людиною. & & & & & \\
\hline 29. & Я вважаю, що життя має бути насиченим та продуктивним. & & & & & \\
\hline 30. & Я настільки зайнятий справами, що не залишається часу для власного розвитку. & & & & & \\
\hline
\end{tabular}

Твердження опитувальника розподілено за трьома шкалами: потреба у саморозвитку, умови саморозвитку, механізми саморозвитку.

Потреба у саморозвитку $(5,6,13,14,20,26,27,28,29,30)$. Зміст шкали становить потреба в самовдосконаленні, особистісному зростанні, усвідомленому самотворенні, відкритість, інтерес до навколишнього, внутрішнього світу свого та інших людей, повнота і насиченість життя, потреба в експансії розширенні світу, оволодінні ним.

Умови саморозвитку $(2,3,4,7,12,16,17,19,23,25)$. Зміст шкали становить автономність, позитивне самосприймання, сила, зрілість Я, визначеність у цілях, активні життєві стратегії (пошукова активність, самовдосконалення), сприйнятливість (толерантність) до нового.

Механізми (функціональні засоби) саморозвитку $(1,8,9,10,11,15,18,21,22,24)$. Зміст шкали становить самопізнання (прагнення до автентичності), самоаналіз (рефлексія), усвідомлення розбіжності між реальним і бажаним Я, чутливість до зворотного зв'язку, здатність до саморегуляції і самотворення.

Потреба у саморозвитку визначається як потреба в самовдосконаленні, особистісному зростанні, усвідомленому самотворенні, відкритість, інтерес до навколишнього, внутрішнього світу свого та інших людей, повнота і насиченість життя, потреба в експансії - розширенні світу, оволодінні ним.

Умови саморозвитку вбачаються у автономності, позитивному самосприйнятті, силі, зрілості Я, визначеності у цілях, активних життєвих стратегіях (пошукова активність, самовдосконалення), сприйнятливість (толерантність) до нового. 
Механізмами (функціональні засоби) саморозвитку $є$ самопізнання (прагнення до автентичності), самоаналіз (рефлексія), усвідомлення розбіжності між реальним і бажаним Я, чутливість до зворотного зв'язку, здатність до саморегуляції і самотворення.

В інструкції респондентам пропонувалося визначити ступінь відповідності твердження власному внутрішньому світу, оцінивши ії від одного до п'яти балів.

\section{ВИСНОВКИ}

За результатами дослідження зроблено наступні висновки.

Відмітимо позитивні зрушення за всіма показниками рефлексивно-оцінювального критерію, що характеризує стан сформованості рефлексивного компонента візуально-інформаційної культури майбутніх учителів математики та інформатики. В експериментальних групах порівняно з контрольними динаміка за показниками P1 та Р2 була більш виразною. Так за показником Р1 отримали приріст $+15,89 \%$ (ЕГ1), $+14,75$ (ЕГ2), +3,16\% (КГ) на високому рівні та $+13,25 \%$ (ЕГ1), +13,93\% (ЕГ2), +8,86 (КГ) на середньому рівні, а за показником Р2 - приріст $+10,6 \%$ (ЕГ1), +10,66\% (ЕГ2), $+5,06 \%$ (КГ) на високому рівні, $+13,25 \%(Е Г 1),+14,75 \%$ (ЕГ2), $+7,59 \%$ (КГ) на середньому рівні.

Наприкінці експерименту студенти проявляли критичне ставлення до обраного ЗКВ в ході написання конспектів уроків чи розв' язування професійних завдань, бажання обговорювати шляхи використання ЗКВ при вивченні певних тем шкільного курсу математики, інформатики з подальшим аналізом та корекцією власної професійної діяльності, усвідомлення типових помилок при застосуванні інформаційних технологій в освітньому процесі, зацікавленість у поповненні власних знань у галузі когнітивної візуалізації за рахунок вивчення досвіду інших, опрацювання науково-методичної літератури.

Приріст у результатах за показником Р1 був прогнозований, оскільки в процесі навчання студенти набувають здатності до рефлексії як складової професійної підготовки. Реалізація педагогічної системи формування візуально-інформаційної культури майбутніх учителів математики та інформатики на рефлексивно-коригувальному етапі дозволила акцентувати увагу на самоаналізі як інструменті оцінювання процесу і результатів власної професійної діяльності у ході написання конспектів фрагментів уроку 3 обов'язковим проведенням та обговоренням у межах виконання залікових лабораторних робіт, під час проходження педагогічної практики, виконання кваліфікаційного дослідження, виконання науково-дослідної роботи.

За показником Р2 спостерігалася менш виразна динаміка на високому рівні сформованості візуальноінформаційної культури майбутніх учителів математики та інформатики порівняно з показником Р1. Пояснюємо це тим, що в процесі діагностики виявляли лише прагнення до самовдосконалення, саморозвитку, а самовдосконалення реалізується власне у процесі професійної діяльності, тобто про реальні результати за цим показником можна буде судити дещо пізніше.

Вважаємо, що позитивним зрушенням за показником Р2 послугували всі впроваджені заходи педагогічної системи формування візуально-інформаційної культури майбутніх учителів математики та інформатики у ході формувального експерименту, оскільки всі вони здійснювалися із застосуванням методів рефлексії діяльності студентів.

\section{Список використаних джерел}

1. Друшляк М. Г. Система формування візуально-інформаційної культури майбутніх учителів математики та інформатики у закладах вищої освіти. Освіта. Інноватика. Практика. 2019. № 2(6). С. 10-17.

2. Друшляк М. Критеріальна база дослідження рівнів сформованості візуально-інформаційної культури майбутніх учителів математики та інформатики. Фізико-математична освіта. 2020. Вип. 4(26). С. 40-44.

3. Друшляк М. Формування візуально-інформаційної культури майбутніх учителів математики та інформатики: мотиваційний критерій. Актуальні питання природничо-математичної освіти. 2020. № 1 (15). С. 91-99.

4. Друшляк М. Формування візуально-інформаційної культури майбутніх учителів математики та інформатики: процесуальний критерій. Актуальні питання природничо-математичної освіти. 2020. № 2 (16). С. 129-137.

5. Друшляк М.Г. Формування візуально-інформаційної культури майбутніх учителів математики та інформатики: пізнавальний критерій. Фізико-математична освіта. 2021. Вип. 3 (29). С. 51-57.

6. Єдина державна електронна база з питань освіти. Реєстр суб'єктів освітньої діяльності. Кількість осіб, зарахованих на навчання. URL: https://registry.edbo.gov.ua/opendata/entrant/ (Дата звернення 28.05.2021).

7. Кузікова С.Б., Кузіков Б.О. Конструювання методики дослідження саморозвитку особистості. Вісник Національного технічного університету України "Київський політехнічний інститут». Філософія. Психологія. Педагогіка, 2010, № 2 (29). С. 106-112. 


\section{References}

1. Drushliak, M. (2019). Systema formuvannia vizualno-informatsiinoi kultury maibutnikh uchyteliv matematyky ta informatyky u zakladakh vyshchoi osvity [The system of formation of pre-service mathematics and computer science teachers' visual and information culture in higher education institutions]. Osvita. Innovatyka. PraktykaEducation. Innovation. Practice. 2(6), 10-17. (in Ukrainian)

2. Drushliak, M. (2020a). Kryterialna baza doslidzhennia rivniv sformovanosti vizualno-informatsiinoi kultury maibutnikh uchyteliv matematyky ta informatyky [Criteria base of researches of levels of formation of pre-service mathematics and computer science teachers' visual and information culture]. Fizyko-matematychna osvita Physical and mathematical education. 4(26), 40-44. (in Ukrainian)

3. Drushliak, M. (2020b). Formuvannia vizualno-informatsiinoi kultury maibutnikh uchyteliv matematyky ta informatyky: motyvatsiinyi kryterii [Formation of pre-service mathematics and computer science teachers' visual and information culture: motivational criterion]. Aktualni pytannia pryrodnycho-matematychnoi osvity-Current issues of natural and mathematical education. 1 (15), 91-99. (in Ukrainian)

4. Drushliak, M. (2020c). Drushliak, M. (2020b). Formuvannia vizualno-informatsiinoi kultury maibutnikh uchyteliv matematyky ta informatyky: protsesualnyi kryterii [Formation of pre-service mathematics and computer science teachers' visual and information culture: procedural criterion]. Aktualni pytannia pryrodnycho-matematychnoi osvity - Current issues of natural and mathematical education. 2 (16). C. 129-137. (in Ukrainian)

5. Drushliak, M. (2021). Formuvannia vizualno-informatsiinoi kultury maibutnikh uchyteliv matematyky ta informatyky: piznavalnyi kryterii [Formation of pre-service mathematics and computer science teachers' visual and information culture: cognitive criterion]. Fizyko-matematychna osvita - Physical and mathematical education. 3 (29). C. 51-57. (in Ukrainian)

6. ledyna derzhavna elektronna baza z pytan osvity. Reiestr subiektiv osvitnoi diialnosti. Kilkist osib, zarakhovanykh na navchannia [The state electronic database on education. Register of subjects of educational activity. Number of persons enrolled in training.]. Retrieved from https://registry.edbo.gov.ua/opendata/entrant/. (in Ukrainian)

7. Kuzikovaб S.B., Kuzikov6 B.O. (2010). Konstruiuvannia metodyky doslidzhennia samorozvytku osobystosti [Designing methods for studying personal self-development]. Visnyk Natsionalnoho tekhnichnoho universytetu Ukrainy "Kyivskyi politekhnichnyi instytut». Filosofiia. Psykholohiia. Pedahohika - Bulletin of the National Technical University of Ukraine "Kyiv Polytechnic Institute". Philosophy. Psychology. Pedagogy. 2 (29), 106-112. (in Ukrainian)

\section{FORMATION OF VISUAL AND INFORMATION CULTURE OF PRE-SERVICE MATHEMATICS AND COMPUTER SCIENCE TEACHERS: REFLEXIVE AND EVALUATIVE CRITERION \\ M.G. Drushlyak \\ Makarenko Sumy State Pedagogical University, Ukraine}

Abstract.

Formulation of the problem. Modern mathematics and computer science teacher must have a high level of visual and information culture, the structure of which necessarily includes a reflective component, which characterized by the ability to analyze, predict and reflect on their own professional activities to visualize educational material using computer visualization means, which provides professional self-development and self-improvement.

Materials and methods. The study was based on scientific research of national and foreign scientists studying the training of pre-service mathematics and computer science teachers. To achieve this goal, the methods of the theoretical level of scientific knowledge were used: analysis of scientific literature, synthesis, formalization of scientific sources, description, comparison, and statistical methods: Pearson's test; Student's t-test.

Results. To determine the level of formation of pre-service mathematics and computer science teachers' visual and information culture, reflexive and evaluative criteria are distinguished, which is characterized by the ability to self-analyze, evaluate and reflexively interpret the results of their professional activities to implement computer visualization in education.

Statistical calculations on the indicators of reflexive-evaluation criterion (critical attitude to the chosen computer visualization means, to the chosen of educational content visualization technology, awareness of typical mistakes in the introduction of information technology in the educational process ( $P 1$ "Ability to self-analysis"); updating and replenishing their own knowledge, skills and abilities in the field of information and mathematical disciplines and digital technologies (P2 "Ability to self-improvement") confirmed the statistical difference of the selected samples: for each pair of samples EG1 - CG and EG2 - CG for each indicator obtained $\left|t_{\text {стат }}\right|>t_{\text {крит }}$ and statistical homogeneity for groups EG1 - EG2, because for each indicator obtained $\left|t_{\text {стат }}\right|<t_{\text {крит }}$.

Conclusions As a result of the implementation of the system of formation of pre-service mathematics and computer science teachers' visual and information culture, students showed a critical attitude to the chosen computer visualization means in writing lesson plans or solving professional problems, desire to discuss ways to use computer visualization means in studying some topics of school mathematics, informatics with further analysis and correction of own professional activity, awareness of common mistakes in the use of information technology in the educational process, interest in replenishing their knowledge in the field of cognitive visualization by studying the experience of others, the development of scientific and methodological literature.

Keywords: visual and information culture, pre-service mathematics and computer science teachers, reflection, reflexive component of visual and information culture, reflexive and evaluative criterion.

\section{$(\mathrm{Cc}) \mathrm{BY}-\mathrm{NC}-\mathrm{SA}$}

This work is licensed under Creative Commons Attribution-NonCommercial-ShareAlike 4.0 International License. 